\title{
Why Do Patients Bleed?
}

\author{
${ }^{1}$ Department of Clinical and Laboratory Hematology, Institute of \\ Clinical Pathology and Medical Research and Westmead Hospital, \\ Sydney Centres for Thrombosis and Hemostasis, Westmead, \\ Australia \\ 2 Pathology West, NSW Health Pathology, Westmead, Australia
}

Jennifer Curnow ${ }^{1}$ Leonardo Pasalic ${ }^{1,2}$ Emmanuel J. Favaloro ${ }^{1,2}$

Address for correspondence Jennifer Curnow, MBBS, FRACP, FRCPA, PhD, Hematology, ICPMR, Westmead, NSW, Australia 2145 (e-mail: Jennifer.curnow@sydney.edu.au).

Surg J 2016;2:e29-e43.
Abstract
Keywords
- surgery
- bleeding
- hemostasis
- platelet function
- coagulation

Patients undergoing surgical procedures can bleed for a variety of reasons. Assuming that the surgical procedure has progressed well and that the surgeon can exclude surgical reasons for the unexpected bleeding, then the bleeding may be due to structural (anatomical) anomalies or disorders, recent drug intake, or disorders of hemostasis, which may be acquired or congenital. The current review aims to provide an overview of reasons that patients bleed in the perioperative setting, and it also provides guidance on how to screen for these conditions, through consideration of appropriate patient history and examination prior to surgical intervention, as well as guidance on investigating and managing the cause of unexpected bleeding.
Patients undergoing surgical procedures can bleed for one or more reasons (summarized in - Table 1). Assuming that the surgical procedure has progressed well and that the surgeon can exclude surgical reasons for the unexpected bleeding, then the bleeding may be due to structural (anatomical) anomalies or disorders, recent drug intake, or disorders of hemostasis, which in turn can be acquired or congenital. This article primarily aims to overview the process of hemostasis and show how deranged hemostasis, whether due to acquired events (including drugs, supplements, among others) or congenital disorders/deficiencies, can give rise to unexpected bleeding. This narrative review also provides guidance on how to screen for these conditions, through consideration of appropriate patient history and examination prior to surgical intervention, as well as providing guidance on investigating and managing the cause of bleeding.

\section{What Is Hemostasis?}

The function of normal hemostasis is to maintain intravascular blood in a fluid state while responding to injury by forming a localized clot to prevent further bleeding and subsequently to remove the thrombus to permit wound healing. ${ }^{1}$ Optimal hemostasis requires a balance between the processes involved in activation (prohemostatic/procoagulant) and inhibition (antihemostatic/anticoagulant). Components that lead to deranged thrombosis essentially comprise those identified by Virchow's triad ( $\boldsymbol{- F i g .} \mathbf{1}$ ). A similar conceptual approach, albeit in the other direction, can be used to describe deranged hemostasis leading to bleeding. The basic components of hemostasis comprise the blood vessel wall (which in turn includes the endothelial cell lining and the subendothelial matrix components such as collagen), the blood components (especially platelets, coagulation factors, and other adhesive proteins), plus various inhibitors and the fibrinolytic system. Intact endothelium has several properties that essentially inhibit thrombus formation in normally flowing blood. ${ }^{2}$ Endothelium is covered by glycocalyx, which contains heparan sulfate, an activator of antithrombin (in turn an inhibitor of hemostasis). Endothelium also expresses thrombomodulin, which binds free thrombin (a potent procoagulant protein) and ADPase. ADPase degrades the platelet agonist adenosine diphosphate (which might otherwise activate platelets). Endothelium also produces tissue plasminogen activator (a protein involved in the breakdown of clots) as well as the vasodilators nitric oxide and prostacyclin., ${ }^{1,3,4}$ Blood vessels constrict in response to injury by smooth muscle contraction, and the microvasculature vasoconstricts in response to endothelin released from endothelial cells and thromboxane released from activated platelets. ${ }^{1,5,6}$ received

November 2, 2015 accepted after revision February 1, 2016
DOI http://dx.doi.org/ 10.1055/s-0036-1579657. ISSN 2378-5128.
Copyright $\odot 2016$ by Thieme Medical Publishers, Inc., 333 Seventh Avenue, New York, NY 10001, USA. Tel: +1(212) 584-4662.

\section{License terms}

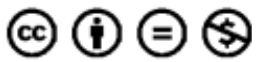


Table 1 A summary of why patients may bleed as a result of surgical procedures

\begin{tabular}{|l|l|}
\hline Why a patient may bleed & Comments \\
\hline $\begin{array}{l}\text { The surgical intervention itself, } \\
\text { including anomalous vasculature } \\
\text { and anatomical anomalies }\end{array}$ & $\begin{array}{l}\text { Surgeons may be reticent to consider this factor, but it is the known cause of most } \\
\text { unexpected bleeds and should be evaluated before/concurrent to investigation of } \\
\text { other possible causes of bleeding; importantly, subtle differences may exist in the } \\
\text { anatomy of individual patients }\end{array}$ \\
\hline Tissue/collagen disorders & Rare; see - Table 2 for a list \\
\hline Drug-related causes & $\begin{array}{l}\text { Antithrombotic/anticoagulant/antiplatelet agents (refer to - Table 3) } \\
\text { Unintended consequences of many supplements } \\
\text { Other drugs }\end{array}$ \\
\hline Other acquired disorders & $\begin{array}{l}\text { Liver disease, vitamin K deficiency, renal failure with uremia, bone marrow failure } \\
\text { due to hematological disorders or chemotherapy treatment } \\
\text { Immune thrombocytopenic purpura } \\
\text { Disseminated intravascular coagulation } \\
\text { Factor inhibitors }\end{array}$ \\
\hline Congenital disorders & $\begin{array}{l}\text { Platelet disorders (primary hemostasis) } \\
\text { von Willebrand disease (primary and secondary hemostasis) } \\
\text { Hemophilias (deficiencies in factors VIII or IX or XI; secondary hemostasis) } \\
\text { Rare bleeding disorders (e.g., defects/deficiencies in fibrinogen, } \\
\text { and factors II, V, VII, X, XIII; usually secondary hemostasis) }\end{array}$ \\
\hline
\end{tabular}

When injury occurs, platelets adhere to von Willebrand factor (VWF) in the exposed subendothelial matrix, via the platelet glycoprotein (Gp) Ib-V-IX receptor. This initial adhesion occurs under high shear flow conditions and is reversible. However, adhesion also triggers platelet activation via GPIIb/IIIa receptor activation, platelet granule release, phospholipid exposure, shedding of microparticles, shape change with formation of pseudopodia, and irreversible binding to matrix ligands, under low shear. ${ }^{7}$ Activated platelet GPIIb/IIIa then mediates platelet aggregation via fibrinogen and VWF. Release of the platelet granule contents and microparticles recruits additional platelets. ${ }^{1,8,9}$ This process is often termed primary hemostasis.
Secondary hemostasis comprises additional processes of coagulation (clotting) and fibrinolysis and can be initiated either directly or by primary hemostasis. ${ }^{1}$ Historically, secondary hemostasis was envisaged as a waterfall or cascade model, as initially proposed in 1964 by Davie and Ratnoff and by Macfarlane. ${ }^{10,11}$ This model described the circulation of coagulation proteins as inactive zymogens, which in the presence of phospholipid and calcium underwent sequential activation to serine proteases. The theory explained the roles of all the known coagulation factors and correlated well with the observations from laboratory testing, especially the plasma-based activated partial

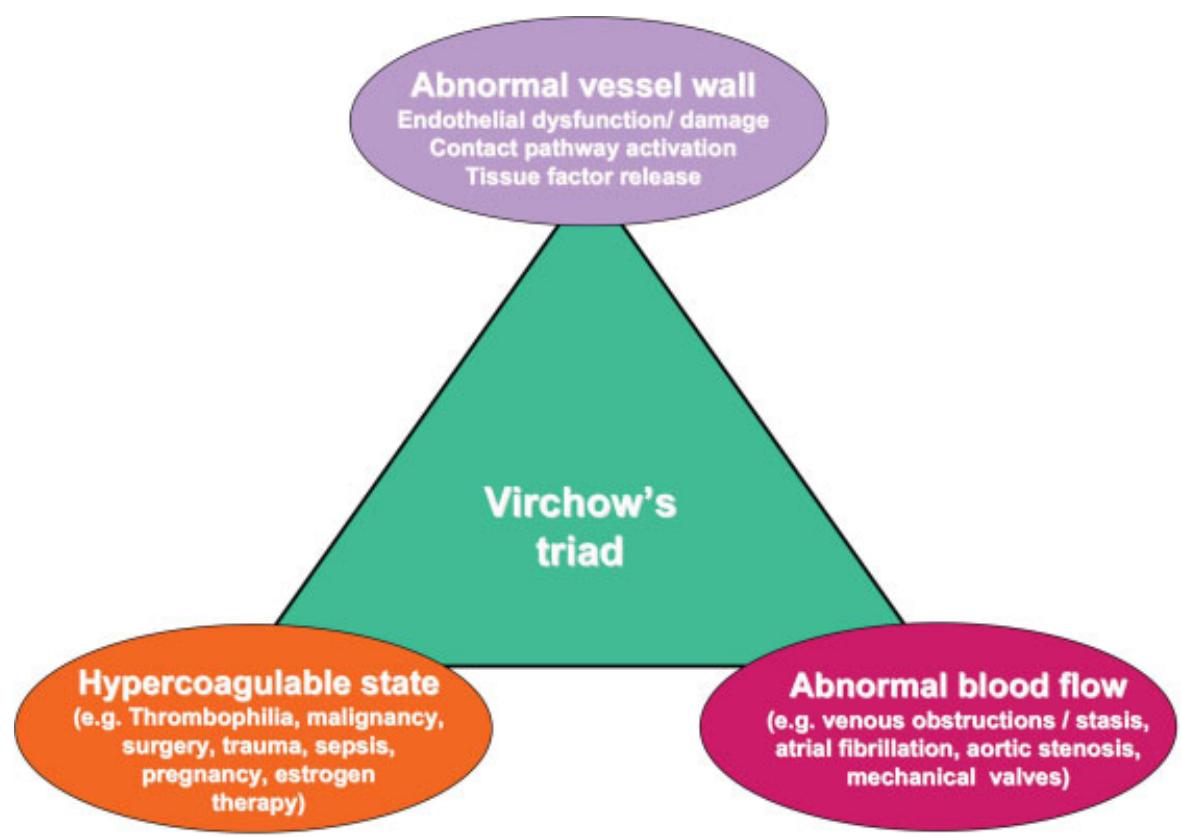

Fig. 1 Virchow's triad. Although this visual describes the basic components contributing to thrombosis, analogous considerations around these concepts can also be applied to bleeding, albeit in the "opposite direction" to thrombosis. 
thromboplastin time (APTT) and prothrombin time (PT) assays (-Fig. 2). ${ }^{12}$

Our current understanding of this process revolves around a cell-based model in which the process of coagulation is initiated by tissue factor (TF). ${ }^{8,12,13}$ In this model, the coagulation process is regulated by cell surface properties, and there are specific cellular receptors for the coagulation proteins, as well as the exposure of negatively charged phospholipids. Three overlapping, rather than sequential, phases of coagulation have now been described: initiation, priming (or amplification), and propagation (-Fig. 3). TF, the primary coagulation trigger in this model, may be derived from the surface of extravascular cells, such as fibroblasts within the vessel wall or from blood-borne microparticles, and can also be expressed by stimulated endothelial cells and monocytes, as well as variety of other sources. ${ }^{14-16}$

During initiation, TF binds to factor VIIa (FVIIa) and activates a small amount of factor IX (FIX) and factor X (FX) directly. At its site of production on the TF-bearing cell, factor $\mathrm{Xa}$ (FXa) activates factor $\mathrm{V}$ and then complexes with factor $\mathrm{Va}$ (FVa), forming the prothrombinase complex, which converts a small amount of prothrombin to thrombin locally. 8,12

In the priming/amplification phase, the small amount of thrombin produced acts on protease-activated receptors to further activate platelets, which release the contents of $\alpha$ granules, including factor FV (FV). ${ }^{17}$ Thrombin cleaves factor VIII (FVIII), leading to its dissociation from VWF, and activates it along with FV and factor XI (FXI), and tissue factor pathway inhibitor inactivates the FVIIa/TF/FXa complex. ${ }^{8,12}$

During propagation, the FIXa produced by TF/FVIIa binds to activated platelets and further FIXa is generated on the platelet surface by FXIa. The tenase complex of FVIIIa/FIXa activates FX, which then complexes with FVa, generating a significant thrombin burst. ${ }^{12,17}$ The main aspects of this process are summarized in -Fig. 3. According to this model, in the absence of FVIII, FIX, or FXI, this amplification and clot propagation are impaired, even though TF still initiates the process. However, the absence of contact activating factors (including factor XII [FXII]) does not impair the coagulation process, which helps explain why deficiencies of FVIII, FIX, and factor XI (FXI) can lead to bleeding but why deficiencies of the contact factors such as FXII do not.

The generated thrombin binds to fibrinogen and cleaves it, releasing fibrinopeptides $\mathrm{A}$ and $\mathrm{B}$, which then polymerize by forming protofibrils with adjacent fibrin molecules. Thrombin also activates factor XIII (FXIII), which stabilizes the fibrin clot by forming cross-links (-Fig. 2). Fibrin networks with tightly cross-linked fibers are less permeable and more resistant to fibrinolysis, ${ }^{18,19}$ which helps to explain why FXIII deficiency is also associated with bleeding.

Fibrinolytic components are localized on the surface of a fibrin clot to mediate fibrin degradation. To facilitate this action, the efficiency of tissue-type plasminogen activator is enhanced in the presence of fibrin. ${ }^{20}$ Tissue-type plasminogen activator

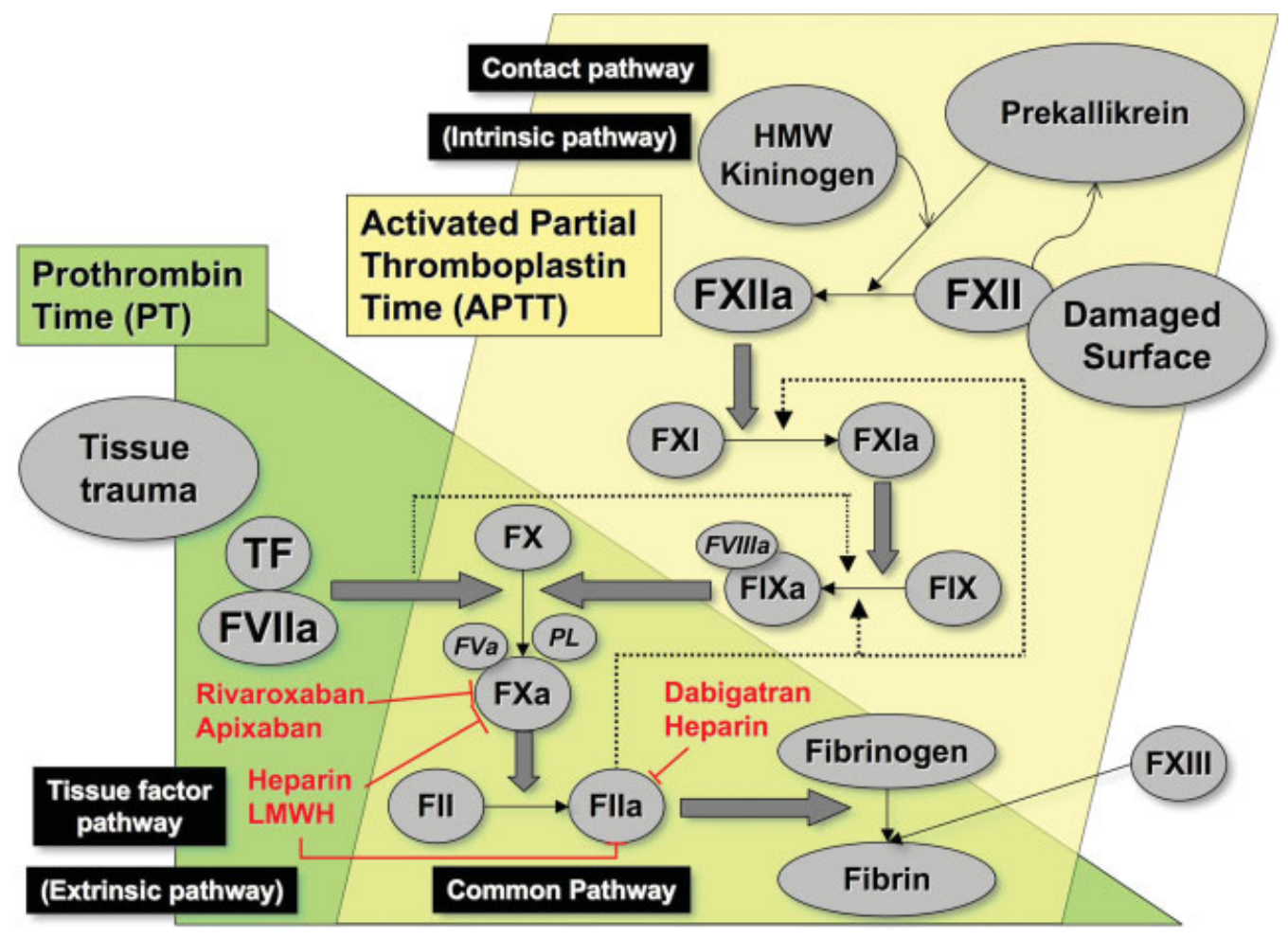

Fig. 2 The concept of intrinsic, extrinsic, and common pathways of coagulation, as representative of the waterfall or cascade models of coagulation, and their relationship to the common coagulation assays. In these assays, reagents contain tissue extracts or recombinant TF (for PT) to mimic the extrinsic pathway and various activators (e.g., ellagic acid, micronized silica) to mimic a damaged surface (for APTT) to imitate the contact or intrinsic pathway. Also shown in this figure are some common anticoagulant control points. The vitamin K antagonists (including warfarin) affect factors II, VII, IX and X. Abbreviations: APTT, activated partial thromboplastin time; F, factor; HMW, high molecular weight; $\mathrm{LMWH}$, low molecular weight heparin; PL, phospholipid; PT, prothrombin time; TF, tissue factor. 

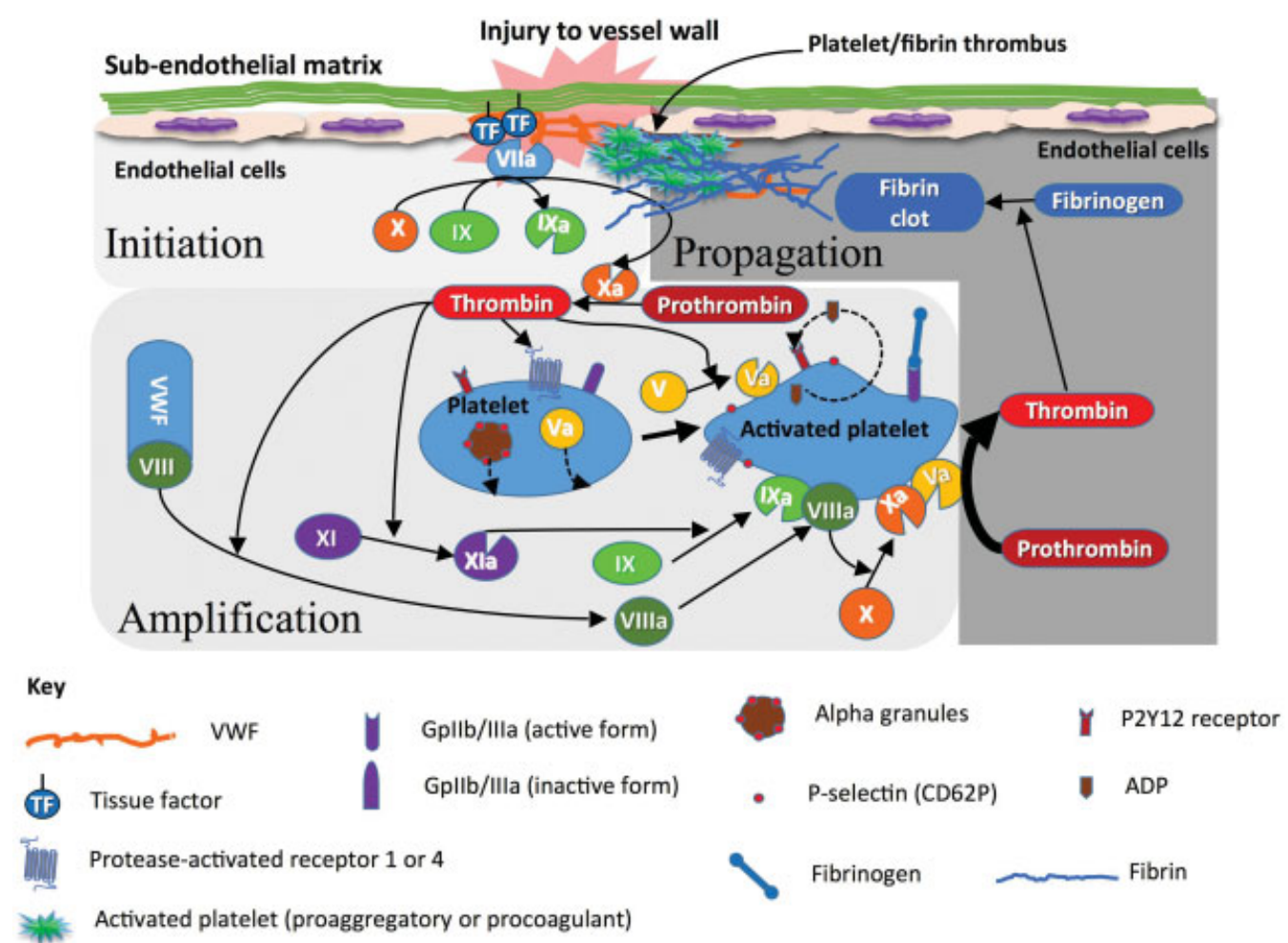

Fig. 3 The cell-based model of coagulation and the concepts of initiation, priming/amplification, and propagation of thrombin generation. Potential defects in primary or secondary hemostasis, as depicted in this figure, can be associated with bleeding.

cleaves plasminogen to the active enzyme plasmin, which produces fibrin degradation products. The fibrinolytic system is tightly controlled by inhibitors. Alpha 2-antiplasmin binds to plasmin to inactivate it, and plasminogen activator inhibitor (PAI-1) complexes with tissue-type plasminogen activator to prevent further plasmin production. In addition, in the presence of thrombomodulin, thrombin activates a further inhibitor of fibrinolysis (thrombin activatable fibrinolysis inhibitor [TAFI]), thus linking the coagulation system with fibrinolysis. TAFI reduces plasminogen binding to the fibrin clot by cleaving the C-terminal lysine and arginine residues from fibrin. ${ }^{21}$

The coagulation pathway is also regulated by inhibitors. In addition to tissue factor pathway inhibitor, which binds the TF/VIIa/Xa complex generated during the initiation phase of coagulation, there are two other major inhibitory mechanisms. Antithrombin inhibits the serine proteases thrombin FXa and to a lesser extent factor XIa (FXIa) and factor IXa (FIXa). The activity of antithrombin is greatly enhanced by heparan sulfate, which also localizes antithrombin action to the endothelial cell surface. The final inhibitory mechanism involves activated protein $\mathrm{C}$, which is aided by its cofactor protein $\mathrm{S}$ and cleaves FVIIla and FVa to inactivate them. Circulating protein $C$ is bound to the endothelial cell by a specific receptor, bringing it into close proximity with the thrombin/thrombomodulin complex, which activates protein C. ${ }^{22}$ Consequently, the inhibitors are also localized at the site of injury and clot formation.

The current model of coagulation emphasizes the central role of thrombin. Thrombin is not merely the enzyme converting fibrinogen to fibrin. It also activates platelet aggregation, endothelium, leukocytes, and factors V, VIII, IX, XI, and XIII, and it triggers activation of the antithrombotic protein $C$ pathway and inhibition of fibrinolysis via TAFI. $^{23,24}$

Thrombin is also involved in the innate immune system and amplifies and modifies inflammatory responses. ${ }^{25}$ The complement system has direct effects on coagulation and interacts with inflammatory mediators. ${ }^{26}$ These effects of thrombin may also be relevant in hypercoagulable states.

Although it is convenient to separate primary and secondary hemostasis in terms of models, the two systems are intricately linked. For example, VWF is a large and complex protein synthesized in endothelial cells and megakaryocytes, ${ }^{27,28}$ and it contributes to both primary and secondary hemostasis. VWF binds to platelets, FVIII, and subendothelial matrix components such as collagen. VWF is thus able to deliver both FVIII and platelets, then localize these to sites of tissue injury, and also further facilitate the adhesion of platelets to each other and to collagen in the subendothelial. ${ }^{29-31}$ Platelets also contain an armamentarium of procoagulant material, including FV, that are delivered and released to the area of tissue injury, as well as expressing many cell surface adhesion molecules that also bind to collagen and fibrinogen in addition to VWF.

As already noted, the entire hemostasis system is tightly controlled by various checks and balances. An inherited or acquired defect in the system may consequently overwhelm the inbuilt compensatory processes and lead to uncontrolled 
bleeding or thrombosis. There are many potential deficiencies or defects now recognized within hemostasis (- Table 2 ), including defects of platelets and clotting factors and VWF. These may lead to platelet disorders, hemophilia, rare bleeding disorders, and von Willebrand disease (VWD), just to name a few such disorders.

\section{How Does Surgery Affect the Process of Hemostasis?}

Surgery and the associated tissue trauma result in various acute changes in the hemostatic system aimed at increasing clot formation and thus minimizing blood loss. Surgical incisions

Table 2 Classification of hereditary and acquired disorders of hemostasis and mechanisms

\begin{tabular}{|c|c|}
\hline & Mechanism \\
\hline \multicolumn{2}{|l|}{ Primary hemostasis } \\
\hline \multicolumn{2}{|l|}{ Hereditary diseases } \\
\hline von Willebrand disease & Impaired platelet adhesion/aggregation \\
\hline Bernard-Soulier syndrome & Impaired platelet adhesion/aggregation \\
\hline Glanzmann thrombasthenia & $\begin{array}{l}\text { Impaired platelet adhesion/aggregation and } \\
\text { Thrombocytopenia }\end{array}$ \\
\hline Platelet storage pool disease & Impaired platelet adhesion/aggregation \\
\hline Gray platelet syndrome & Impaired platelet adhesion/aggregation \\
\hline May-Hegglin anomaly & Macrothrombocytopenia \\
\hline Wiskott-Aldrich syndrome & Microthrombocytopenia \\
\hline \multicolumn{2}{|l|}{ Acquired disorders } \\
\hline Immune thrombocytopenic purpura & Thrombocytopenia \\
\hline Drug-induced immune thrombocytopenia (e.g., quinine, sulfonamides) & Thrombocytopenia \\
\hline Drug-induced platelet dysfunction (e.g., antiplatelet therapies, NSAIDs) & Impaired adhesion and/or aggregation \\
\hline Mechanical platelet destruction (e.g., cardiac bypass) & Thrombocytopenia \\
\hline Disseminated intravascular coagulation & $\begin{array}{l}\text { Thrombocytopenia and secondary } \\
\text { hemostatic defects, including hyperfibrinolysis }\end{array}$ \\
\hline Renal failure with uremia & Impaired platelet aggregation and secretion \\
\hline Liver disease & $\begin{array}{l}\text { Rebalanced hemostasis with } \\
\text { multiple abnormalities }\end{array}$ \\
\hline \multicolumn{2}{|l|}{ Secondary hemostasis } \\
\hline \multicolumn{2}{|l|}{ Hereditary diseases } \\
\hline Hemophilia A (factor VIII deficiency) & Impaired coagulation \\
\hline Hemophilia B (factor IX deficiency) & Impaired coagulation \\
\hline Rare bleeding disorders: deficiencies in factors II, V, VII, X, XI & Impaired coagulation \\
\hline Factor XIII deficiency & Impaired coagulation \\
\hline Afibrinogenemia/hypofibrinogenemia & Impaired coagulation \\
\hline nherited dysfibrinogenemias & Impaired coagulation \\
\hline Ehlers-Danlos syndrome & Connective tissue disorder \\
\hline Hereditary hemorrhagic telangiectasia & Connective tissue disorder \\
\hline \multicolumn{2}{|l|}{ Acquired disorders } \\
\hline Acquired inhibitors of specific coagulation factors & Impaired coagulation \\
\hline Vitamin K deficiency & Impaired coagulation \\
\hline Afibrinogenemia/hypofibrinogenemia (DIC) & Impaired coagulation \\
\hline Hyperfibrinolysis & Increased fibrinolysis \\
\hline Vitamin C deficiency (scurvy) & Connective tissue disorder \\
\hline Anticoagulant ingestion & Impaired coagulation \\
\hline Liver disease & $\begin{array}{l}\text { Rebalanced hemostasis with } \\
\text { multiple abnormalities }\end{array}$ \\
\hline
\end{tabular}

Abbreviations: DIC, disseminated intravascular coagulation; NSAIDs, nonsteroidal anti-inflammatory drugs. 
release TF from endothelial and other tissue sources, initiating the process of coagulation. If inflammation or infection are present in the region requiring surgery, then cytokines such as tumor necrosis factor and interleukin-6 will accelerate coagulation. ${ }^{32,33}$ Antithrombin complexes with the generated thrombin and is rapidly consumed during surgery, contributing to a degree of hypercoagulability proportional to the extent of tissue trauma. ${ }^{34}$ Surgery also affects the levels of fibrinolytic factors acutely. Tissue plasminogen activator levels rise in the first few hours but decrease toward normal by 24 hours, and levels of PAI- 1 rise fivefold within 2 hours then gradually decrease over 1 to 2 days with a secondary peak at 7 days; the overall effect is a temporary impairment of fibrinolysis. . $^{32,33,35,36}$ The levels of microparticles also increase in response to surgery and trauma, and these microparticles are recruited into areas of developing clot, contributing to its propagation. ${ }^{37}$

Medications administered during surgery, ambient conditions, and surgical techniques also variably affect hemostasis. For example, anesthetic agents may induce stasis and venodilatation, which increase thrombosis risk, ${ }^{38,39}$ whereas some agents increase the bleeding risk ( - Table 3). Prolonged severe hypothermia $\left(<32^{\circ} \mathrm{C}\right)$ and acidosis both impair hemostasis and should be optimized in any bleeding patient. ${ }^{40}$ These conditions also impact on coagulation testing and may produce abnormal laboratory test results in the absence of any specific factor deficiency. Hetastarch has been associated with increased post-coronary artery bypass grafting hemorrhage, but no differences in hemostasis were seen with the use of normal saline or Ringer's lactate. ${ }^{41}$ Use of a tourniquet in total knee replacement increases fibrinolysis and reduces hypercoagulability. ${ }^{42}$

Some surgical procedures are associated with particular changes in hemostatic function that require specific knowledge for recognition and appropriate preventative action to avoid excessive bleeding. Cardiopulmonary bypass surgery is an example of surgery associated with complex hemostatic changes. Activation of hemostasis occurs while on bypass, and heparin is routinely used to prevent thrombosis; however, its use in combination with inflammation and hemodilution also contributes to blood loss. ${ }^{43}$ Other contributors to bleeding may be deficiency of fibrinogen, thrombocytopenia or impaired platelet function, reduced generation of thrombin, hyperfibrinolysis, or surgical bleeding. ${ }^{43,44}$ Endothelial disruption and consumption of antithrombin potentially contribute to thrombotic risks. ${ }^{44}$ Thromboelastography, a whole blood point of care assay that assesses viscoelastic clot properties, has been used in this setting to distinguish the factors contributing to bleeding and guide replacement of prohemostatic agents or drug therapies including protamine to reverse the effect of heparin, antifibrinolytics, platelet transfusions, administration of coagulation factor concentrates, and cryoprecipitate or fibrinogen. ${ }^{43,44}$

\section{What Causes Bleeding and How Can Different Causes Be Recognized?}

Excessive bleeding, greater than expected by the surgeon, is reported in $\sim 3 \%$ of all procedures. ${ }^{45}$ In 75 to $90 \%$ of cases, intraoperative and early postoperative bleeding result from a technical defect. ${ }^{46,47}$ Although arterial and venous bleeding requires surgical intervention with cautery, pressure, ligature, or tamponade for hemostasis, control of bleeding in the microcirculation requires an intact hemostatic system. Thus, distinguishing the different causes for bleeding is crucial, and the clinical features may provide some clues. A structural defect requiring surgical intervention is more likely to be the cause of bleeding that occurs from a single site, is of sudden onset, and/or represents a massive hemorrhage or pulsatile bleeding where a source is evident. A hemostatic defect is the more likely cause when bleeding occurs at multiple sites simultaneously, such as the surgical site in addition to vascular access sites and mucous membranes, skin, or nonoperative hematuria. Hemorrhage that is delayed and occurs after a period of adequate hemostasis or a slow persistent ooze of blood without an obvious source also suggests a defect in hemostasis. ${ }^{46,47}$ For example, previously undiagnosed mild hemophilia is a rare cause of surgical bleeding but typically is associated with normal hemostasis intraoperatively and in the initial postoperative period when large amounts of TF are present due to tissue injury. Subsequently, when TF levels fall, a slow but persistent ooze commences between days 1 and 3 postoperatively. $^{48}$

Intraoperative hemorrhage is most commonly caused by structural defects, anticoagulant excess, hyperfibrinolysis, or a generalized and severe disorder of hemostasis, such as disseminated intravascular coagulation. Early postoperative hemorrhage (within 2 days of surgery) suggests a defect in primary hemostasis, such as significant thrombocytopenia (platelet count less than $50 \times 10^{9} / \mathrm{L}$ ) or platelet dysfunction, each of which may be inherited or acquired. Mild to moderate inherited disorders of coagulation, such as VWD, may present with early bleeding. Delayed postoperative hemorrhage (onset between days 2 to 7 ) may also be seen with these causes and in addition with defects in secondary hemostasis, involving coagulation factors, fibrinogen, or connective tissue disorders. Examples of the conditions associated with delayed hemorrhage include vitamin K deficiency, multiorgan failure, recommencement of antiplatelet agents, or anticoagulation, and it has also been reported with the development of antibodies to FV or thrombin associated with bovine thrombin used in fibrin glue. ${ }^{49,50}$ Thus, the time frame of bleeding onset gives an indication of likely causes for bleeding. Potential hereditary or acquired causes are listed in -Table 2.

In liver disease, the situation is more complex. Recent theory suggests that hemostasis has been "rebalanced" in patients with liver disease compared with healthy individuals, which has important implications for perioperative management. $^{51-55}$ Liver synthesis of coagulation factors is reduced, which results in prolongation of the PT and APTT, which in turn can lead to the misconception that these patients are autoanticoagulated or have a tendency to bleed similar to that seen in patients taking vitamin $\mathrm{K}$ antagonists with comparable coagulation assay prolongation. In fact, in liver disease, the normal synthesis of anticoagulant proteins antithrombin, protein $C$, and protein $S$ is also impaired, providing a counterbalance to the reduced coagulation factors (which is not detected by routine coagulation assays). The liver also synthesizes some components of the fibrinolytic 
Table 3 Drugs that affect hemostasis

\begin{tabular}{|c|c|c|}
\hline & Drug & Drug target/receptor(s) \\
\hline \multicolumn{3}{|c|}{ Drugs that affect platelet function } \\
\hline \multirow[t]{6}{*}{ Intentional } & Aspirin & COX-1 \\
\hline & Clopidogrel, ticlopidine, prasugrel, ticagrelor, cangrelor & P2Y12 receptor \\
\hline & Abciximab, eptifibatide, tirofiban & GP IIb/IIla (fibrinogen receptor) \\
\hline & Dipyrdamole & PDE \\
\hline & Cilostazol & PDE3 \\
\hline & Vorapaxar & PAR1 \\
\hline \multirow[t]{7}{*}{ Incidental } & $\begin{array}{l}\text { Many drugs and supplements, for example, NSAIDs: } \\
\text { meclofenamic acid, mefenamic acid, diclofenac, ibu- } \\
\text { profen, indomethacin, naproxen, tolmetin, zomepirac, } \\
\text { piroxicam, diflunisal, sulindac }\end{array}$ & COX-1 (reversible inhibition) \\
\hline & Antibiotics (penicillins and cephalosporins) & $\begin{array}{l}\text { Interaction with platelet receptors, membrane con- } \\
\text { stituents and/or VWF }\end{array}$ \\
\hline & $\begin{array}{l}\text { Cardiovascular drugs (nitrates, beta-adrenergic recep- } \\
\text { tor blockers, calcium channel blockers, angiotensin- } \\
\text { converting enzyme inhibitors, angiotensin receptor } \\
\text { blockers, antiarrhythmic drugs) }\end{array}$ & Various mechanisms \\
\hline & Lipid-lowering drugs (HMG-CoA inhibitors [statins]) & $\begin{array}{l}\text { Changes in lipid composition of the platelet plasma } \\
\text { membrane; inhibition of GTP-binding proteins? }\end{array}$ \\
\hline & Plasma expanders (dextrans, hydroxyethyl starch) & Interaction with platelet membrane constituents \\
\hline & $\begin{array}{l}\text { Antihistamines, radiographic contrast agents, psycho- } \\
\text { tropic drugs (tricyclic antidepressants, phenothiazines, } \\
\text { selective serotonin reuptake inhibitors), chemothera- } \\
\text { peutic agents, anesthetics and narcotics, }\end{array}$ & Various mechanisms \\
\hline & $\begin{array}{l}\text { Foods, spices, vitamins and herbal supplements (gin- } \\
\text { ger, onion, vitamin E, cumin, turmeric, cloves, alcohol, } \\
\text { omega-3 fatty acids, Chinese black tree fungus, garlic, } \\
\text { berries, caffeine, cocoa, dark chocolate, kiwi fruit, } \\
\text { purple grape juice, red wine, white wine, tomato, } \\
\text { turmeric/curcumin, andrographis, cranberry, danshen, } \\
\text { dong quai, feverfew, ginkgo, ginseng, green tea, haw- } \\
\text { thorn, motherwort, St. John's wort, turmeric, willow } \\
\text { bark) }\end{array}$ & Various mechanisms \\
\hline \multicolumn{3}{|c|}{ Drugs that affect coagulation } \\
\hline \multirow[t]{5}{*}{ Intentional } & $\begin{array}{l}\text { UFH, LMWH, lepirudin, argatroban, bivalirudin, } \\
\text { dabigatran }\end{array}$ & Thrombin \\
\hline & $\begin{array}{l}\text { UFH, LMWH, fondaparinux, danaparoid, apixaban, ri- } \\
\text { varoxaban, edoxaban }\end{array}$ & $\mathrm{Xa}$ \\
\hline & Vitamin K antagonists (e.g., warfarin) & Factors II, VII, IX, and X \\
\hline & Thrombolytic agents (streptokinase, urokinase, t-PA) & Fibrin/fibrinogen \\
\hline & $\begin{array}{l}\text { Antifibrinolytic agents (E-aminocaproic acid, tranexa- } \\
\text { mic acid) }\end{array}$ & Fibrinolysis \\
\hline \multirow[t]{3}{*}{ Incidental } & Super-warfarins (“rat poison”) & Factors II, VII, IX, and X \\
\hline & $\begin{array}{l}\text { Foods, spices, vitamins and herbal supplements (gin- } \\
\text { seng, danshen, dong quai, St. John's wort, cranberry) }\end{array}$ & Various mechanisms \\
\hline & Plasma expanders (dextrans, hydroxyethyl starch) & \\
\hline
\end{tabular}

Abbreviations: COX, cyclooxygenase; HMG-CoA, 3-hydroxy-3-methylglutaryl-coenzyme A; GP, glycoprotein; GTP, guanosine triphosphate; LMWH, low-molecular-weight heparin; NSAIDs, non-steroidal anti-inflammatory drugs; PAR, protease-activated receptor; PDE, phosphodiesterase; t-PA, tissue-type plasminogen activator; UFH, unfractionated heparin; VWF, von Willebrand factor.

Note: This list is not meant to be exhaustive, but contains some common as well as less well-recognized agents that affect hemostasis. Summarized from various references, especially references ${ }^{67-69}$.

anlike all other agents listed in this table, antifibrinolytic agents do not increase bleeding risk. 
system and is responsible for their clearance, consequently some studies have shown a hyperfibrinolytic state in liver disease. ${ }^{51-55}$ Furthermore, the production of thrombopoietin, which stimulates the production of megakaryocytes (the bone marrow precursor to platelets), is impaired and thus contributes to thrombocytopenia, as does platelet sequestration within the enlarged spleen due to portal hypertension. This condition is partially compensated by increased VWF due to reduced liver clearance and possibly increased endothelial production and/or release. Thus, the rebalanced hemostatic state is not reflected by the results of routine APTT and PT assays. Although maintaining a platelet count above $50 \times 10^{9} /$ L has been shown to reduce perioperative bleeding, prophylactic preprocedure correction of PT and APTT has not. Similarly, liver disease does not protect patients from thrombotic events, and venous thromboembolism prophylaxis should not be withheld. ${ }^{51-55}$

\section{How Can a Surgeon Predict Perioperative Bleeding?}

It is not always possible to predict whether an individual patient will bleed excessively during surgery or postoperatively. However, taking a patient's history and physical examination targeted toward detection of hemostatic defects are by far the best aids in predicting surgical bleeding. ${ }^{56-59}$ Three large studies examined preoperative hemostatic testing and found no correlation between preoperative coagulation screening tests and surgical bleeding due to a preponderance of sample collection or handling errors, laboratory errors, or the presence of "apparent hemostasis abnormalities" such as a lupus anticoagulant or FXII deficiency, which prolong APTT but are not associated with clinical bleeding. ${ }^{60-62}$ of 4,499 patients, 85 bled during surgery, $70 \%$ of whom had normal coagulation tests. Of the 435 patients with abnormal coagulation tests, $97 \%$ did not bleed. The coagulation screening tests showed a sensitivity of $18 \%$ for surgical bleeding and specificity of $90 \%$ with a positive predictive value of only $3 \%$ and negative predictive value of 98\%. A history of bleeding was 12.5 times more likely to predict bleeding during subsequent surgery than laboratory screening tests. ${ }^{63}$ Furthermore, up to two thirds of patients with abnormal screening tests when investigated further did not have a bleeding diathesis and were not at risk of surgical bleeding. ${ }^{64}$ Consequently, testing should be utilized to further evaluate patients whose history indicates a possible bleeding diathesis and for those undergoing major surgery, particularly surgery with high bleeding risk such as procedures involving the central nervous system, cardiopulmonary bypass surgery, or prostatectomy. ${ }^{47,65}$

Inappropriate testing or screening all surgical candidates without regard for clinical history increases the risk that statistical, preanalytical, and analytical errors will produce false-positive results. ${ }^{66}$ These results will lead to further invasive investigations, increased patient anxiety, and greater utilization of health care resources including laboratory staff time, laboratory resources, and clinical staff time to obtain an appropriate history and try to determine the significance of screening results, as well as potentially delaying surgery unnecessarily. Normal screening tests may also provide false reassurance that a patient is not at risk of bleeding, because many bleeding disorders are not detected by routine screening tests, as discussed above.

When taking a history to screen for abnormal hemostasis, the following questions should be addressed: Has the patient or any family member ever experienced abnormal bleeding or been described as a "bleeder"? Has the patient bled with previous surgery, procedures, dental extractions, or childbirth? Did the bleeding require return to the operating theater for hemostatic control, or did it necessitate blood transfusion or transfusion of other products? Has the female patient had menorrhagia? If so, this finding should be quantified and the requirement for iron supplementation or treatment of anemia questioned. A history of spontaneous bruising at multiple sites, recurrent spontaneous epistaxis, and hemorrhage following trauma or sport should also be sought. If the patient has ever required blood or plasma transfusion, then the reason should be determined. More detailed questioning or hematologist consultation may be advised if these screening questions indicate a possible underlying bleeding disorder.

The preoperative history should also evaluate the patient's medications and recent drug and supplement intake. Many drugs and supplements affect hemostasis, including platelet function and coagulation (-Table 3). ${ }^{67-69}$ Apart from the more obvious (intentionally prescribed) anticoagulant/antithrombotic/antiplatelet agents, the history should also evaluate other recently ingested agents. For example, many herbs and supplements used in traditional Chinese medicine have antihemostatic effects, many drugs affect platelet function, and even some common pain killers (including nonsteroidal anti-inflammatory agents) can potentially increase the risk of bleeding.

\section{How Can the Cause of Bleeding Be Diagnosed?}

Although a history of bleeding is invaluable in distinguishing different causes of hemostatic defects, it is not always available in the acutely bleeding surgical patient, who may never have had such a challenge of hemostatic function previously. Urgent investigation and empiric therapy may be required. A fresh peripheral venipuncture should be used for urgent blood sampling to avoid contamination by infused products or anticoagulants. A full blood count, APTT, PT, thrombin time, fibrinogen, and D-dimer should be requested urgently. ${ }^{70}$ If available, a platelet function screen using a platelet function analyzer-100/200 may further inform, especially if platelet count and hematocrit are normal. ${ }^{71}$ Liaison with the hematologist will enable close collaboration with the coagulation laboratory to ensure appropriate sequential testing. Discussion with the hematologist about the type of bleeding observed and any pre-existing risk factors such as abnormal screening coagulation tests, use of anticoagulants, or antiplatelet therapy will also assist in making a specific diagnosis. Mixing studies and specific coagulation factor testing or VWD 
screening may be expedited if indicated by the initial tests (-Figs. 4 and $\mathbf{5}$ ). ${ }^{70}$ It may be necessary to exclude an acquired inhibitor. - Table 4 indicates likely patterns of abnormal coagulation test results in patients with specific disorders of hemostasis. Attention should also be given to pre-existing abnormal liver or renal function, anesthesia time, patient temperature, ionized calcium concentration, and $\mathrm{pH}$. Abnormalities should be corrected, and urgent empiric therapy may be initiated. -Figs. 4 and $\mathbf{5}$, respectively, provide further guidance in the situations where mixing studies of initially abnormal PT and/or APTT tests correct (thus suggesting a factor deficiency) or do not fully correct (thus suggesting an inhibitor).

For example, VWD is considered the most common inherited bleeding disorder with an estimated prevalence up to $1 \%$; it is due to deficiency and/or defects in the plasma protein VWF. ${ }^{29,72,73}$ VWD is classified on the basis of quantitative deficiencies of VWF (VWD types 1 and 3) or qualitative defects in VWF (type 2 VWD), which may or may not be also associated with a quantitative deficiency of VWF. Bleeding in VWD is typically of the mucocutaneous type with menorrhagia, epistaxis, gum bleeds, or gastrointestinal bleeds reflecting the function of VWF in adhesion of platelets and subendothelial matrix. A further consequence of the reduced, absent, or dysfunctional VWF is loss of the protective function of plasma FVIII against proteolysis. Thus, the coassociated deficiency of FVIII will also contribute to bleeding events in a secondary picture that is more typical of hemophilia A with muscular hematomas, joint bleeds, or postsurgical bleeding from large wounds. Treatment replaces both missing components, VWF and FVIII.
Disorders of platelet function should be investigated if the bleeding looks mucosal in origin but VWD testing is normal. ${ }^{74}$

For patients already known to have a bleeding disorder, preoperative assessment by a hematologist should be undertaken to optimize the perioperative management of the disorder. In more severe bleeding disorders, surgery should be performed in a setting with appropriate medical, nursing, and laboratory supports, such as a hemophilia treatment center.

Deficiency of FXII is a more common cause of APTT prolongation than mild hemophilia. Deficiencies of contact factors (FXII, high-molecular-weight kininogen, and prekallikrein) do not require replacement for surgery but will cause prolongation of the baseline APTT and activated clotting time; consequently, these assays are unsuitable for monitoring anticoagulant therapy in some patients, for example, those having cardiac surgery. Such cases should be discussed with the hematologist and alternative assays such as anti-Xa activity or thrombin generation may be available.

\section{How Should Unexpected Bleeding due to Hemostatic Defects Be Treated?}

Urgent resuscitation should be instituted without delay, including acute volume replacement and red cell transfusion if indicated. Massive transfusion protocols for major bleeding usually recommend proportional replacement of red cells, platelets, fresh frozen plasma, and cryoprecipitate to prevent coagulopathy due to dilutional losses of platelets and coagulation factors. If bleeding decreases following these measures, then it may be appropriate to watch and wait while additional coagulation tests are conducted. If bleeding continues, then re-

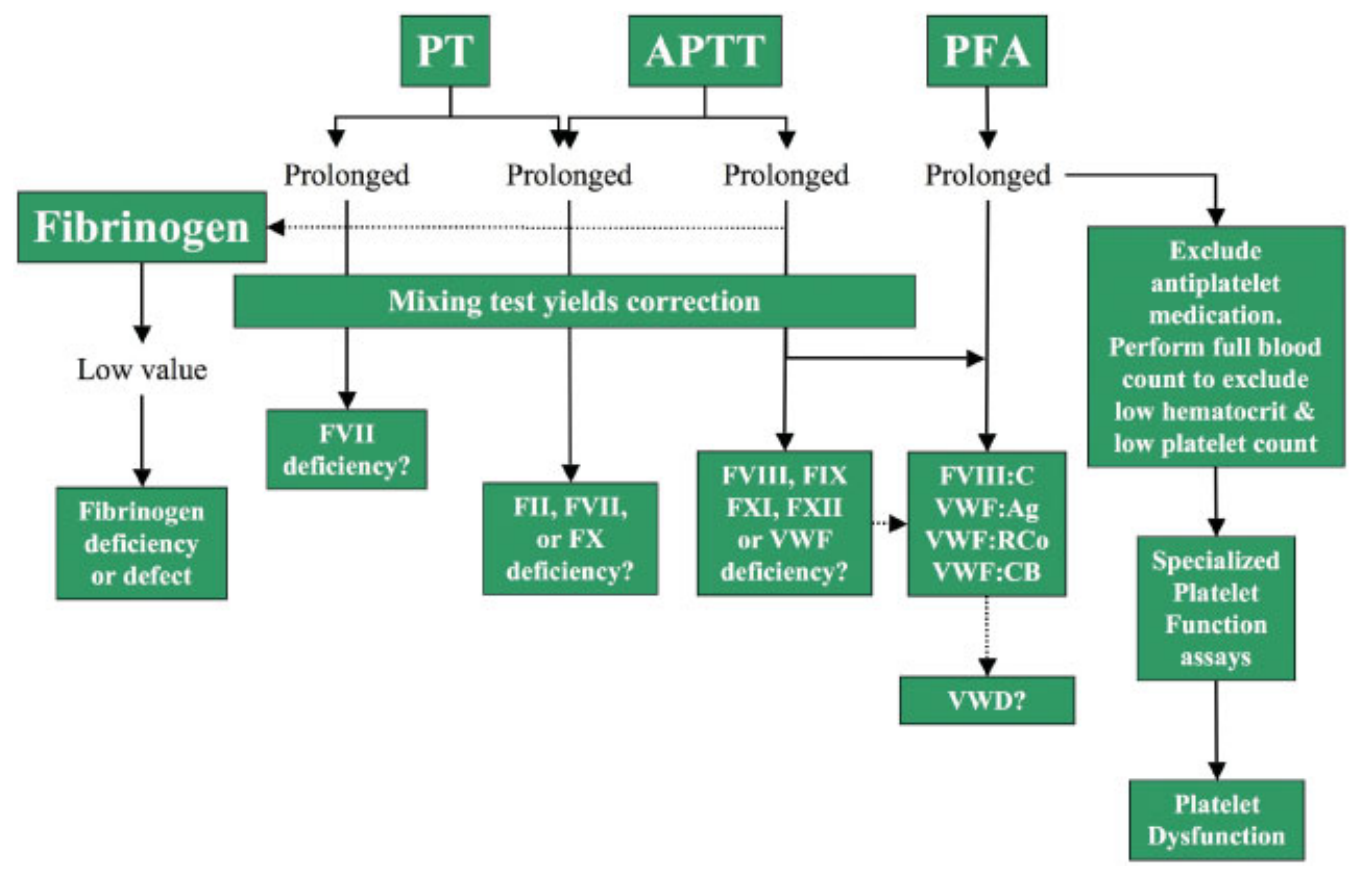

Fig. 4 An algorithm that describes a simple approach to the initial investigation of a bleeding patient, or to otherwise screen for hemostasis defects, where simple mixing studies correct and suggest a factor deficiency. Abbreviations: APTT, activated partial thromboplastin time; F, factor; PFA, platelet function analyzer; PT, prothrombin time; VWD, von Willebrand disease; VWF, von Willebrand factor; C, coagulant; Ag, antigen; RCo, ristocetin cofactor; $\mathrm{CB}$, collagen binding. 


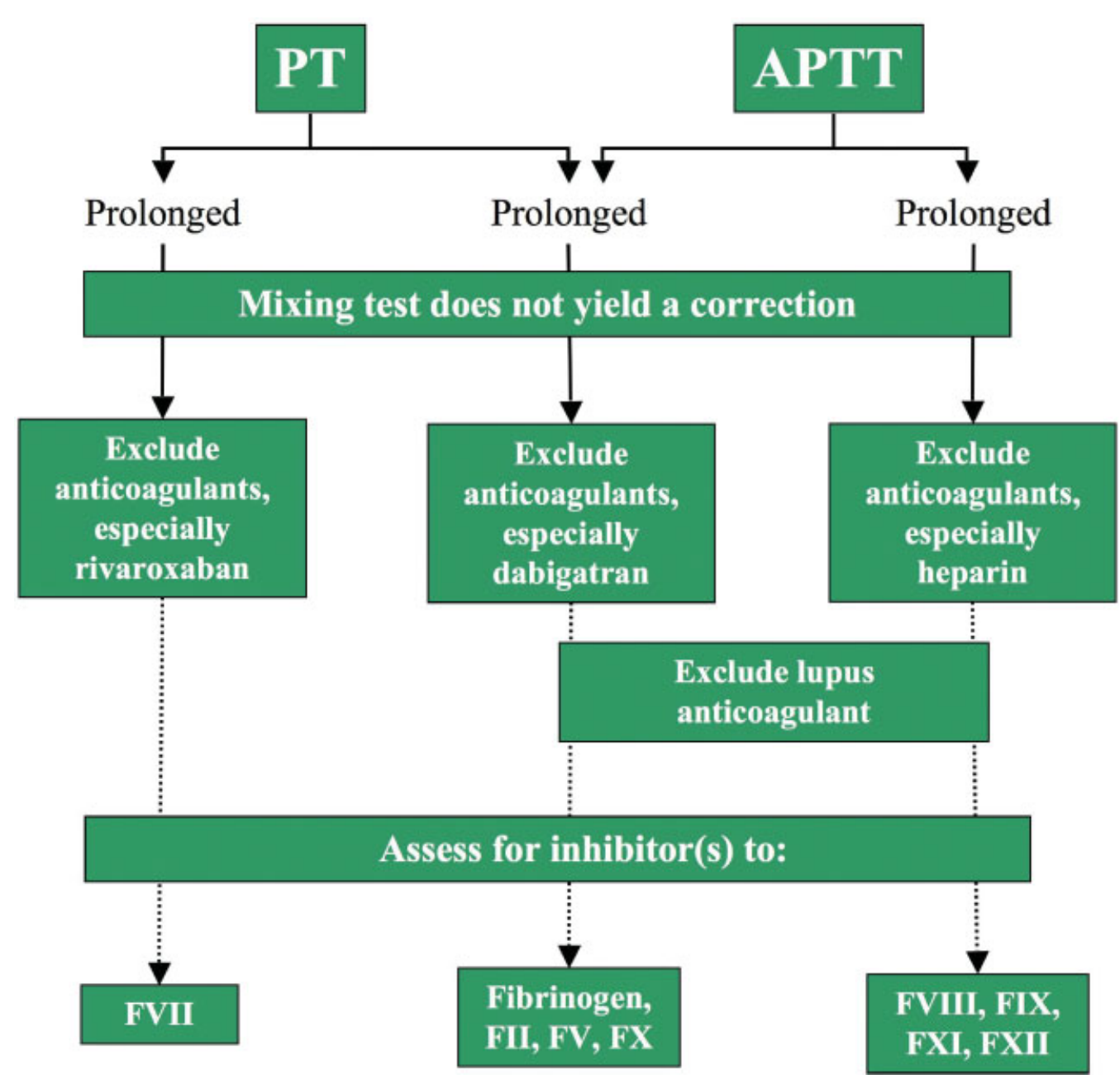

Fig. 5 An algorithm that describes a simple approach to the initial investigation of a bleeding patient, or to otherwise screen for hemostasis defects, where simple mixing studies do not correct and suggest the presence of an inhibitor. Abbreviations: APTT, activated partial thromboplastin time; F, factor; PT, prothrombin time.

exploration of the surgical bed or bleeding site may be indicated. In some circumstances, specific procedures such as angiography with or without arterial embolization may be indicated. Infusion of desmopressin (DDAVP ${ }^{\circledR}$, Ferring Pharmaceuticals Ltd, West Drayton, United Kingdom; $0.3 \mu \mathrm{g} / \mathrm{kg}$ in $50 \mathrm{~mL}$ normal saline over 30 minutes) produces a two- to fivefold increase from baseline in VWF levels in responders and may also improve platelet function in uremic patients. ${ }^{75,76} \mathrm{By}$ 24 hours, levels generally return to baseline. ${ }^{72,77}$ Doses may be repeated up to 72 hours but responses diminish due to depletion of VWF stores, described as tachyphylaxis. Adverse effects include facial flushing, hypertension or hypotension, tachycardia, headache, gastrointestinal upset, and hyponatremia, rarely complicated by seizures. Myocardial infarction has rarely been reported, and thus desmopressin should be avoided in patients with increased risk for cardiovascular and cerebrovascular disease. ${ }^{72}$ Fluid restriction and monitoring of electrolytes is recommended in all cases, particularly when repeat doses are used. In cases of suspected VWD and where DDAVP response is inadequate or contraindicated, treatment entails replacing the missing VWF and FVIII, aiming to increase levels to normal (-Table 5).
Adjunctive therapies such as antifibrinolytics should also be considered. Bleeding is more likely to occur with oral procedures and prostate or urologic surgery due to the presence of the natural profibrinolytic urokinase in saliva and urine, which will dissolve hemostatic clots in wounds. Tranexamic acid $(20 \mathrm{mg} / \mathrm{kg}$ orally or intravenously every 8 hours) or $\varepsilon$-aminocaproic acid ( 2 g orally every 8 hours) will inhibit plasmin generation and prevent excessive fibrinolysis.

Patients with specific inhibitors of coagulation factors, especially FVIII, whether known or unexpected, are at particularly high risk of bleeding. Activated prothrombin complex concentrates such as FVIII inhibitor bypassing agent may be effective and is typically given as an initial bolus of $100 \mathrm{U} / \mathrm{kg}$ followed by $50 \mathrm{U} / \mathrm{kg}$ every 8 to 12 hours. ${ }^{78,79}$ Recombinant FVIIa is useful in patients with inhibitors to FVIII or FIX and has been used in FXI deficiency but has been associated with increased risk of thrombosis when used in the setting of trauma or unexplained surgical hemorrhage, without evidence of mortality benefit. ${ }^{80}$

Inherited deficiencies of fibrinogen, factor II, FV, combined factor V and VIII, FVII, FX, FXI, and FXIII are collectively referred to as rare bleeding disorders, with predominantly 


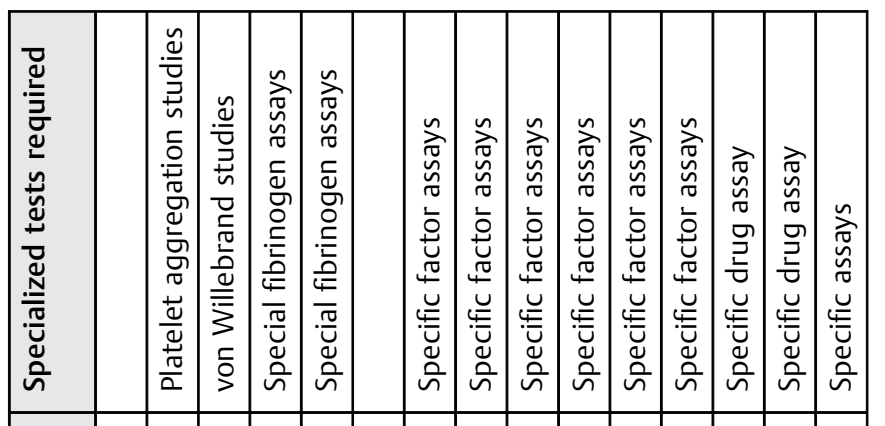

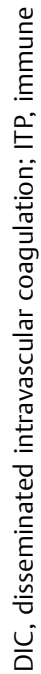

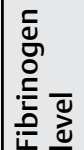

离

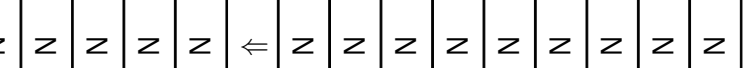

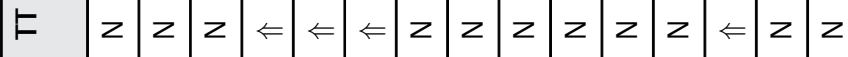

ح

$\widehat{z}$

$\underline{\underline{\underline{y}}} \cdot \underline{\underline{\underline{x}}}$

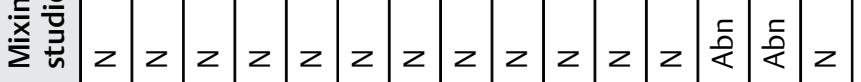

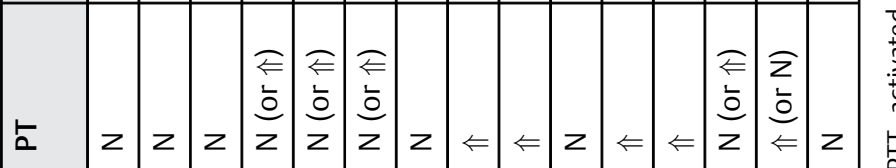

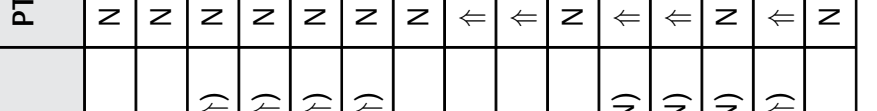

就

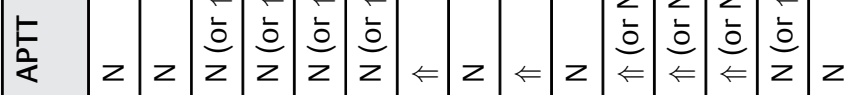

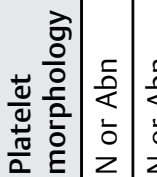

告

\begin{tabular}{ll|l|l|l|l|l|}
\hline & & & & & & \\
\hline & & &
\end{tabular}

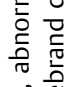

产弯

苑

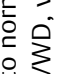

$\begin{array}{lllllllllllllllll}\frac{0}{\alpha} E & \text { E } & z & z & z & z & z & z & z & z & z & z & z & z & z & z & z\end{array}$ 这

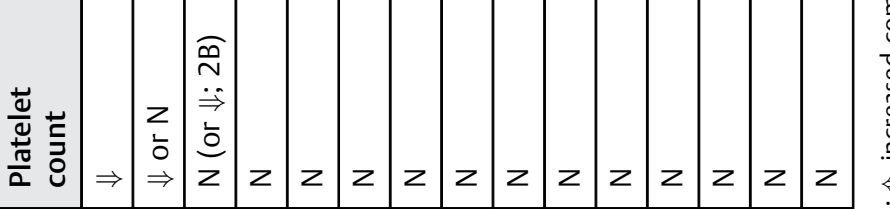

毫

岁点.

$\stackrel{E}{E}$

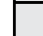

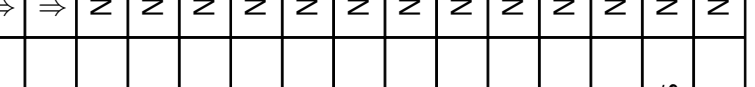

है.

要

菖

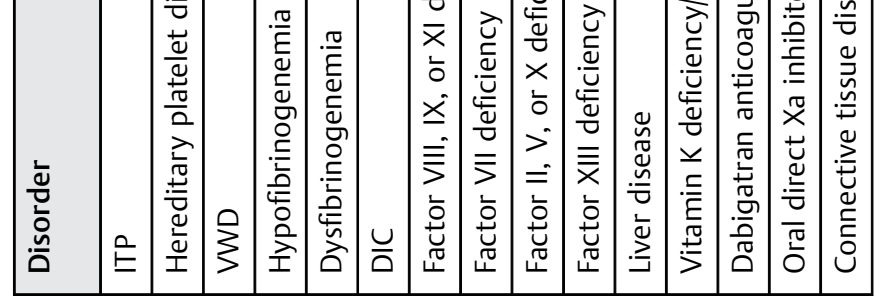

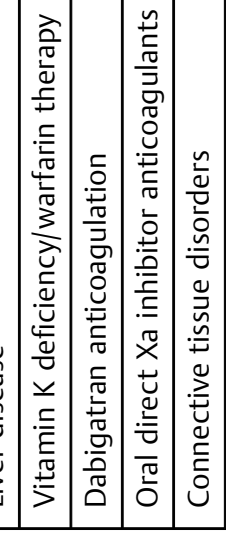


Table 5 A summary of current therapies for major bleeding or surgery in patients with hereditary disorders of hemostasis

\begin{tabular}{|c|c|c|c|}
\hline Disorder & Main therapies & $\begin{array}{l}\text { Initial dose in major } \\
\text { surgery/bleeding }\end{array}$ & $\begin{array}{l}\text { Initial therapeutic target for } \\
\text { treatment of major bleeding }\end{array}$ \\
\hline VWD type 1 & $\begin{array}{l}\text { DDAVP } \\
\text { VWF(/FVIII) concentrate }\end{array}$ & $\begin{array}{l}\text { DDAVP } 0.3 \mu \mathrm{g} / \mathrm{kg} \\
40-60 \mathrm{U} / \mathrm{kg} \text { in VWF:RCo IU } / \mathrm{dL}\end{array}$ & $\begin{array}{l}\text { Trough VWF:RCo and } \\
\text { FVIII }>50 \mathrm{IU} / \mathrm{dL}\end{array}$ \\
\hline VWD type $2 \mathrm{~A}, 2 \mathrm{M}, 2 \mathrm{~N}$ & $\begin{array}{l}\text { VWF(/FVIII) concentrate } \\
\text { DDAVP }\end{array}$ & $\begin{array}{l}40-60 \mathrm{U} / \mathrm{kg} \text { in VWF:RCo IU } / \mathrm{dL} \\
0.3 \mu \mathrm{g} / \mathrm{kg}\end{array}$ & $\begin{array}{l}\text { Trough VWF:RCo and } \\
\text { FVIII > } 50 \mathrm{IU} / \mathrm{dL}\end{array}$ \\
\hline VWD type 2B, type 3 & VWF(/FVIII) concentrate & 40-60 U/kg in VWF:RCo IU/dL & $\begin{array}{l}\text { Trough VWF:RCo and } \\
\text { FVIII }>50 \mathrm{IU} / \mathrm{dL}\end{array}$ \\
\hline Hemophilia A & FVIII concentrates & $\begin{array}{l}\text { Dose varies with severity } \\
(1 \mathrm{U} / \mathrm{kg} \text { raises plasma level by } \\
2 \mathrm{U} / \mathrm{dL})\end{array}$ & FVIII $80-100 \mathrm{IU} / \mathrm{dL}$ \\
\hline Hemophilia B & FIX concentrates & $\begin{array}{l}\text { Dose varies with severity } \\
(1 \mathrm{U} / \mathrm{kg} \text { raises plasma level by } \\
1 \mathrm{U} / \mathrm{dL})\end{array}$ & FIX 80-100 IU/dL \\
\hline $\begin{array}{l}\text { Hypofibrinogenemia, } \\
\text { dysfibrinogenemia }\end{array}$ & $\begin{array}{l}\text { Cryoprecipitate } \\
\text { Fibrinogen concentrate }\end{array}$ & $\begin{array}{l}15-20 \mathrm{~mL} / \mathrm{kg} \\
50-100 \mathrm{mg} / \mathrm{kg}\end{array}$ & Fibrinogen $1 \mathrm{~g} / \mathrm{L}$ or higher \\
\hline Prothrombin deficiency & $\begin{array}{l}\text { Fresh frozen plasma } \\
\text { PCCs }\end{array}$ & $\begin{array}{l}15-25 \mathrm{~mL} / \mathrm{kg} \\
20-40 \mathrm{U} / \mathrm{kg}\end{array}$ & $>20 \mathrm{IU} / \mathrm{dL}$ \\
\hline Factor $\mathrm{V}$ deficiency & Fresh frozen plasma & $15-25 \mathrm{~mL} / \mathrm{kg}$ & $>15-20 \mathrm{IU} / \mathrm{dL}$ \\
\hline Factor VII deficiency & $\begin{array}{l}\text { FVII concentrate if available } \\
\text { PCC } \\
\text { rFVIIa }\end{array}$ & $\begin{array}{l}30-40 \mathrm{~mL} / \mathrm{kg} \\
20-30 \mathrm{U} / \mathrm{kg} \\
15-30 \mu \mathrm{g} / \mathrm{kg} \text { every } 4-6 \mathrm{~h}\end{array}$ & $>20 \mathrm{IU} / \mathrm{dL}$ \\
\hline Factor $\mathrm{X}$ deficiency & $\begin{array}{l}\text { Fresh frozen plasma } \\
\text { PCC }\end{array}$ & $\begin{array}{l}10-20 \mathrm{~mL} / \mathrm{kg} \\
20-30 \mathrm{U} / \mathrm{kg}\end{array}$ & $>20 \mathrm{IU} / \mathrm{dL}$ \\
\hline Factor XI deficiency & $\begin{array}{l}\text { Fresh frozen plasma } \\
\text { FXI concentrate }\end{array}$ & $\begin{array}{l}15-20 \mathrm{~mL} / \mathrm{kg} \\
15-20 \mathrm{U} / \mathrm{kg}\end{array}$ & $15-20 \mathrm{IU} / \mathrm{dL}$ \\
\hline Factor XIII deficiency & $\begin{array}{l}\text { Cryoprecipitate } \\
\text { rFXIII if available }\end{array}$ & $\begin{array}{l}2-3 \text { units } \\
35 \mathrm{U} / \mathrm{kg}\end{array}$ & $30 \%$ \\
\hline Ehlers-Danlos syndrome & $\begin{array}{l}\text { No specific therapy; ascorbic } \\
\text { acid supplementation or } \\
\text { DDAVP perioperatively }\end{array}$ & & \\
\hline
\end{tabular}

Abbreviations: F, factor; PCC, prothrombin complex concentrate; $\mathrm{rF}$, recombinant factor; VWD, von Willebrand disease; RCo, ristocetin cofactor. Note: Summarized from several references, especially references ${ }^{91-95}$.

autosomal-recessive inheritance. ${ }^{81,82}$ Symptoms vary from mild to severe and may not be evident until a surgical challenge occurs. Correction of deficiency is achieved with fresh frozen plasma, cryoprecipitate, or specific factor concentrates where available. - Table 5 summaries specific therapies that are available for the treatment of surgical bleeding once a specific diagnosis has been made or is suspected.

Allogeneic blood components are widely used for surgical bleeding; however, for some patients transfusions are not acceptable on religious grounds. ${ }^{83}$ It should be determined preoperatively which blood components and procedures are acceptable to the individual patient. Hematinic deficiencies should be corrected preoperatively to optimize baseline hemoglobin. Blood salvage techniques and local hemostatic agents should be implemented to minimize blood loss. These principles of patient blood management are applicable to all patients and have shown that outcomes can be achieved that are similar to those for patients who do accept transfusions. ${ }^{83}$

Additional and alternate strategies may need to be employed in the case where unexpected bleeding is associated with the use of unrecognized or even recognized anti- coagulation/antiplatelet therapy. ${ }^{84-86}$ Principles of managing bleeding include withdrawal of the anticoagulant or antiplatelet agent, supportive care, and administration of a specific antidote if it is available. Vitamin $\mathrm{K}$ antagonists, such as warfarin, may be acutely reversed with prothrombin complex concentrate (20 to $50 \mathrm{U} / \mathrm{kg}$ ) or if contraindicated in the specific patient, by using fresh frozen plasma. Vitamin $\mathrm{K}$ is a specific antidote but it takes at least 12 hours to work. ${ }^{87}$ Protamine sulfate binds to and inactivates unfractionated heparin and is dosed at $1 \mathrm{mg}$ per $100 \mathrm{U}$ of heparin given in the preceding 2 to 3 hours. It may also be used for lowmolecular-weight heparin ( $1 \mathrm{mg}$ per $100 \mathrm{Xa}$ units given in last 8 hours) but is only partially effective because it binds to the longer chain molecules only. It is ineffective for reversal of the pentasaccharide fondaparinux. ${ }^{87}$ The oral direct thrombin inhibitor dabigatran now has a specific antidote, idarucizumab (Praxbind ${ }^{\circledR}$, Boehringer Ingelheim, Ingelheim, Germany), an antibody fragment with a very high affinity for dabigatran that recently received U.S. Food and Drug Administration approval. Interim analysis of the phase III REVERSE-AD trial showed immediate and sustained reversal 
of the anticoagulant effect of dabigatran as measured by coagulation assays with a $5 \mathrm{~g}$ intravenous dose. ${ }^{88}$ Patients who received the agent preoperatively for urgent surgery were thought by the operating surgeon to subsequently have normal hemostasis during the procedure in 92\% of cases. Andexanet is a specific reversal agent for Xa inhibitors, both oral and parenteral, which is administered as an intravenous infusion, but it is still undergoing phase III trials. Limited data supports the use of prothrombin complex concentrate for major bleeding. ${ }^{87}$ Although specific assays are now available to measure plasma concentrations of the direct oral anticoagulants, ${ }^{89}$ the drug levels at which surgery may be undertaken safely have not been established. Local hemostatic measures are often sufficient to control bleeding associated with antiplatelet therapies. However, for surgery at critical sites such as intracranial, spinal, or ophthalmologic procedures, platelet transfusion and/or DDAVP $(0.3 \mu \mathrm{g} / \mathrm{kg})$ is often utilized, despite a lack of evidence for their effectiveness for clinical bleeding in this setting. ${ }^{90}$

\section{Conclusions}

As highlighted by this narrative review, patients can bleed for a large variety of reasons in the perioperative setting, including surgical and anatomical anomalies/disorders, recent drug intake, or disturbances of hemostasis. We provide guidance on how to screen for these conditions, as well as for investigation of the cause of bleeding and interpreting the relevant laboratory investigations. We also outline several management strategies. The identification and management of any specific bleeding lesion remains crucial. Where local hemostatic control is not possible, then supportive measures as well as specific therapies may be necessary. Although some hemostatic agents may be given empirically, selected urgently performed laboratory tests and consultation with the hematologist may establish a specific diagnosis and enable refinement of the management of bleeding in the perioperative setting. Careful preoperative assessment, to identify patients with a history of bleeding or those having taken any of the large number of antiplatelet and anticoagulant agents now available, will also enable appropriate preoperative drug cessation or hemostatic agent administration to prevent major bleeding. The future may provide further refinement in these strategies, as the newer hemostatic agents become more widely available. ${ }^{90}$

\section{References}

1 Laffan M, Manning R. Investigation of hemostasis. In: Lewis S, Bain B, Bates I, eds. Dacie and Lewis Practical Hematology. London, UK: Churchill Livingstone; 2001:339-390

2 Kazmi RS, Boyce S, Lwaleed BA. Homeostasis of hemostasis: the role of endothelium. Semin Thromb Hemost 2015;41(6):549-555

3 Fay WP, Garg N, Sunkar M. Vascular functions of the plasminogen activation system. Arterioscler Thromb Vasc Biol 2007;27(6): 1231-1237

4 van Hinsbergh VW. Endothelium-role in regulation of coagulation and inflammation. Semin Immunopathol 2012;34(1):93-106

5 Vanhoutte PM, Tang EH. Endothelium-dependent contractions: when a good guy turns bad!.J Physiol 2008;586(Pt 22):5295-5304
6 Félétou M, Huang Y, Vanhoutte PM. Endothelium-mediated control of vascular tone: COX-1 and COX-2 products. Br J Pharmacol 2011;164(3):894-912

7 Berndt MC, Ward CM, De Luca M, et al. The molecular mechanism of platelet adhesion. Aust N Z J Med 1995;25(6):822-830

8 Hoffman M, Monroe DM III. A cell-based model of hemostasis. Thromb Haemost 2001;85(6):958-965

9 Roberts HR, Hoffman M, Monroe DM. A cell-based model of thrombin generation. Semin Thromb Hemost 2006;32 (Suppl 1):32-38

10 Davie EW, Ratnoff OD. Waterfall sequence for intrinsic blood clotting. Science 1964;145(3638):1310-1312

11 MacFarlane RG. An enzyme cascade in the blood clotting mechanism, and its function as a biological amplifier. Nature 1964; 202:498-499

12 Monroe DM, Hoffman M, Roberts HR. Platelets and thrombin generation. Arterioscler Thromb Vasc Biol 2002;22(9):1381-1389

13 Hoffman M, Monroe DM, Oliver JA, Roberts HR. Factors IXa and Xa play distinct roles in tissue factor-dependent initiation of coagulation. Blood 1995;86(5):1794-1801

14 Bogdanov VY, Versteeg HH. "Soluble tissue factor" in the 21st century: definitions, biochemistry, and pathophysiological role in thrombus formation. Semin Thromb Hemost 2015;41(7):700-707

15 Cimmino G, Ciccarelli G, Golino P. Role of tissue factor in the coagulation network. Semin Thromb Hemost 2015;41(7): 708-717

16 Maugeri N, Manfredi AA. Tissue factor expressed by neutrophils: another piece in the vascular inflammation puzzle. Semin Thromb Hemost 2015;41(7):728-736

17 Heemskerk JWM, Mattheij NJA, Cosemans JMEM. Platelet-based coagulation: different populations, different functions. J Thromb Haemost 2013;11(1):2-16

18 Scott EM, Ariëns RA, Grant PJ. Genetic and environmental determinants of fibrin structure and function: relevance to clinical disease. Arterioscler Thromb Vasc Biol 2004;24(9):1558-1566

19 Schroeder V, Kohler HP. Factor XIII deficiency: an update. Semin Thromb Hemost 2013;39(6):632-641

20 Kwaan HC, Mazar AP. Biologic role of the plasminogen-plasmin system: thrombolysis, bleeding, and beyond. Semin Thromb Hemost 2013;39(4):327-328

21 Rijken DC, Lijnen HR. New insights into the molecular mechanisms of the fibrinolytic system. J Thromb Haemost 2009;7(1):4-13

22 Dahlbäck B. Advances in understanding pathogenic mechanisms of thrombophilic disorders. Blood 2008;112(1):19-27

23 Lane DA, Philippou H, Huntington JA. Directing thrombin. Blood 2005;106(8):2605-2612

24 Mann KG, Brummel K, Butenas S. What is all that thrombin for? J Thromb Haemost 2003;1(7):1504-1514

25 Chen D, Dorling A. Critical roles for thrombin in acute and chronic inflammation. J Thromb Haemost 2009;7(Suppl 1):122-126

26 Markiewski MM, Nilsson B, Ekdahl KN, Mollnes TE, Lambris JD. Complement and coagulation: strangers or partners in crime? Trends Immunol 2007;28(4):184-192

27 Jaffe EA, Hoyer LW, Nachman RL. Synthesis of von Willebrand factor by cultured human endothelial cells. Proc Natl Acad Sci U S A 1974;71(5):1906-1909

28 Sporn LA, Chavin SI, Marder VJ, Wagner DD. Biosynthesis of von Willebrand protein by human megakaryocytes. J Clin Invest 1985; 76(3):1102-1106

29 Sadler JE, Budde U, Eikenboom JC, et al; Working Party on von Willebrand Disease Classification. Update on the pathophysiology and classification of von Willebrand disease: a report of the Subcommittee on von Willebrand Factor. J Thromb Haemost 2006;4(10):2103-2114

30 Yee A, Kretz CA. Von Willebrand factor: form for function. Semin Thromb Hemost 2014;40(1):17-27

31 Peyvandi F, Garagiola I, Baronciani L. Role of von Willebrand factor in the haemostasis. Blood Transfus 2011;9(Suppl 2):s3-s8 
32 Koh SC, Pua HL, Tay DH, Ratnam SS. The effects of gynaecological surgery on coagulation activation, fibrinolysis and fibrinolytic inhibitor in patients with and without ketorolac infusion. Thromb Res 1995;79(5-6):501-514

33 Sørensen JV. Levels of fibrinolytic activators and inhibitors in plasma after severe trauma. Blood Coagul Fibrinolysis 1994; 5(1):43-49

34 Borgstrom S, Gelin LE, Zederfeldt B. The formation of vein thrombi following tissue injury: an experimental study in rabbits. Acta Chir Scand Suppl 1959;247(Suppl 247):1-36

35 Kluft C, Verheijen JH, Jie AF, et al. The postoperative fibrinolytic shutdown: a rapidly reverting acute phase pattern for the fastacting inhibitor of tissue-type plasminogen activator after trauma. Scand J Clin Lab Invest 1985;45(7):605-610

36 Kambayashi J, Sakon M, Yokota M, Shiba E, Kawasaki T, Mori T. Activation of coagulation and fibrinolysis during surgery, analyzed by molecular markers. Thromb Res 1990;60(2):157-167

37 Myers DD, Hawley AE, Farris DM, et al. P-selectin and leukocyte microparticles are associated with venous thrombogenesis. J Vasc Surg 2003;38(5):1075-1089

38 Hamer JD, Malone PC, Silver IA. The PO2 in venous valve pockets: its possible bearing on thrombogenesis. Br J Surg 1981;68(3): 166-170

39 Comerota AJ, Stewart GJ, Alburger PD, Smalley K, White JV. Operative venodilation: a previously unsuspected factor in the cause of postoperative deep vein thrombosis. Surgery 1989; 106(2):301-308, discussion 308-309

40 Martini WZ. Coagulopathy by hypothermia and acidosis: mechanisms of thrombin generation and fibrinogen availability. J Trauma 2009;67(1):202-208, discussion 208-209

41 Avorn J, Patel M, Levin R, Winkelmayer WC. Hetastarch and bleeding complications after coronary artery surgery. Chest 2003;124(4):1437-1442

42 Aglietti P, Baldini A, Vena LM, Abbate R, Fedi S, Falciani M. Effect of tourniquet use on activation of coagulation in total knee replacement. Clin Orthop Relat Res 2000;(371):169-177

43 Levy JH, Sniecinski RM. Prohemostatic treatment in cardiac surgery. Semin Thromb Hemost 2012;38(3):237-243

44 Ranucci M. Hemostatic and thrombotic issues in cardiac surgery. Semin Thromb Hemost 2015;41(1):84-90

45 Collins R, Scrimgeour A, Yusuf S, Peto R. Reduction in fatal pulmonary embolism and venous thrombosis by perioperative administration of subcutaneous heparin. Overview of results of randomized trials in general, orthopedic, and urologic surgery. N Engl J Med 1988;318(18):1162-1173

46 Bevan DH. Cardiac bypass haemostasis: putting blood through the mill. Br J Haematol 1999;104(2):208-219

47 Woodman RC, Harker LA. Bleeding complications associated with cardiopulmonary bypass. Blood 1990;76(9):1680-1697

48 Kitchens CS. Occult hemophilia. Johns Hopkins Med J 1980;146(6): 255-259

49 Zumberg MS, Waples JM, Kao KJ, Lottenberg R. Management of a patient with a mechanical aortic valve and antibodies to both thrombin and factor $\mathrm{V}$ after repeat exposure to fibrin sealant. Am J Hematol 2000;64(1):59-63

50 Favaloro EJ, Posen J, Ramakrishna R, et al. Factor V inhibitors: rare or not so uncommon? A multi-laboratory investigation. Blood Coagul Fibrinolysis 2004;15(8):637-647

51 Weeder PD, Porte RJ, Lisman T. Hemostasis in liver disease: implications of new concepts for perioperative management. Transfus Med Rev 2014;28(3):107-113

52 Stellingwerff M, Brandsma A, Lisman T, Porte RJ. Prohemostatic interventions in liver surgery. Semin Thromb Hemost 2012;38(3): 244-249

53 Tripodi A. Liver disease and hemostatic (dys)function. Semin Thromb Hemost 2015;41(5):462-467

54 Lisman T, Kwaan HC. Hemostatic dysfunction in liver diseases. Semin Thromb Hemost 2015;41(5):445-446
55 Hoffman M. Coagulation in liver disease. Semin Thromb Hemost 2015;41(5):447-454

56 Narr BJ, Warner ME, Schroeder DR, Warner MA. Outcomes of patients with no laboratory assessment before anesthesia and a surgical procedure. Mayo Clin Proc 1997;72(6):505-509

57 Toker A, Shvarts S, Perry ZH, Doron Y, Reuveni H. Clinical guidelines, defensive medicine, and the physician between the two. Am J Otolaryngol 2004;25(4):245-250

58 Chee YL, Crawford JC, Watson HG, Greaves M; British Committee for Standards in Haematology. Guidelines on the assessment of bleeding risk prior to surgery or invasive procedures. $\mathrm{Br} J$ Haematol 2008;140(5):496-504

59 Bowie EJW, Owen CA Jr. The significance of abnormal preoperative hemostatic tests. Prog Hemost Thromb 1980;5:179-209

60 Burk CD, Miller L, Handler SD, Cohen AR. Preoperative history and coagulation screening in children undergoing tonsillectomy. Pediatrics 1992;89(4 Pt 2):691-695

61 Haberman RS II, Shattuck TG, Dion NM. Is outpatient suction cautery tonsillectomy safe in a community hospital setting? Laryngoscope 1990;100(5):511-515

62 Suchman AL, Mushlin AI. How well does the activated partial thromboplastin time predict postoperative hemorrhage? JAMA 1986;256(6):750-753

63 Bachmann F. Diagnostic approach to mild bleeding disorders. Semin Hematol 1980;17(4):292-305

64 Kitchens CS. Prolonged activated partial thromboplastin time of unknown etiology: a prospective study of 100 consecutive cases referred for consultation. Am J Hematol 1988;27(1):38-45

65 Rapaport SI. Preoperative hemostatic evaluation: which tests, if any? Blood 1983;61(2):229-231

66 Lippi G, Favaloro EJ, Franchini M. Dangers in the practice of defensive medicine in hemostasis testing for investigation of bleeding or thrombosis: part I-routine coagulation testing. Semin Thromb Hemost 2014;40(7):812-824

67 Scharf RE. Drugs that affect platelet function. Semin Thromb Hemost 2012;38(8):865-883

68 McEwen BJ. The influence of diet and nutrients on platelet function. Semin Thromb Hemost 2014;40(2):214-226

69 McEwen BJ. The influence of herbal medicine on platelet function and coagulation: a narrative review. Semin Thromb Hemost 2015; 41(3):300-314

70 Lippi G, Pasalic L, Favaloro EJ. Detection of mild inherited disorders of blood coagulation: current options and personal recommendations. Expert Rev Hematol 2015;8(4):527-542

71 Favaloro EJ. Clinical utility of the PFA-100. Semin Thromb Hemost 2008;34(8):709-733

72 Nichols WL, Hultin MB, James AH, et al. von Willebrand disease (VWD): evidence-based diagnosis and management guidelines, the National Heart, Lung, and Blood Institute (NHLBI) Expert Panel report (USA). Haemophilia 2008;14(2):171-232

73 Favaloro EJ. Von Willebrand disease: local diagnosis and management of a globally distributed bleeding disorder. Semin Thromb Hemost 2011;37(5):440-455

74 Favaloro EJ, Bodó I, Israels SJ, Brown SA. von Willebrand disease and platelet disorders. Haemophilia 2014;20(Suppl 4):59-64

75 Kim JH, Baek CH, Min JY, Kim JS, Kim SB, Kim H. Desmopressin improves platelet function in uremic patients taking antiplatelet agents who require emergent invasive procedures. Ann Hematol 2015;94(9):1457-1461

76 Lee HK, Kim YJ, Jeong JU, Park JS, Chi HS, Kim SB. Desmopressin improves platelet dysfunction measured by in vitro closure time in uremic patients. Nephron Clin Pract 2010;114(4): c248-c252

77 Rodeghiero F. Von Willebrand disease: pathogenesis and management. Thromb Res 2013;131(Suppl 1):S47-S50

78 Franchini M, Crestani S, Frattini F, Sissa C, Bonfanti C. Hemostatic agents for bleeding: recombinant-activated factor VII and beyond. Semin Thromb Hemost 2015;41(3):342-347 
79 Tjønnfjord GE, Brinch L, Gedde-Dahl T III, Brosstad FR. Activated prothrombin complex concentrate (FEIBA) treatment during surgery in patients with inhibitors to FVIII/IX. Haemophilia 2004; 10(2):174-178

80 Lin Y, Moltzan CJ, Anderson DR; National Advisory Committee on Blood and Blood Products. The evidence for the use of recombinant factor VIIa in massive bleeding: revision of the transfusion policy framework. Transfus Med 2012;22(6):383-394

81 Othman M. Rare bleeding disorders: genetic, laboratory, clinical, and molecular aspects. Preface. Semin Thromb Hemost 2013; 39(6):575-578

82 Peyvandi F, Menegatti M, Palla R. Rare bleeding disorders: worldwide efforts for classification, diagnosis, and management. Semin Thromb Hemost 2013;39(6):579-584

83 Shander A, Javidroozi M. The approach to patients with bleeding disorders who do not accept blood-derived products. Semin Thromb Hemost 2013;39(2):182-190

84 Darvish-Kazem S, Douketis JD. Perioperative management of patients having noncardiac surgery who are receiving anticoagulant or antiplatelet therapy: an evidence-based but practical approach. Semin Thromb Hemost 2012;38(7):652-660

85 Franchini M, Bonfanti C, Mannucci PM. Management of bleeding associated with new oral anticoagulants. Semin Thromb Hemost 2015;41(7):788-801

86 Cervellin G, Benatti M, Bonfanti L, Lippi G. Quality and safety issues of direct oral anticoagulants in the emergency department. Semin Thromb Hemost 2015;41(3):348-354
87 Goy J, Crowther M. Approaches to diagnosing and managing anticoagulant-related bleeding. Semin Thromb Hemost 2012; 38(7):702-710

88 Pollack CV Jr, Reilly PA, Eikelboom J, et al. Idarucizumab for dabigatran reversal. N Engl J Med 2015;373(6):511-520

89 Favaloro EJ, Lippi G. Laboratory testing in the era of direct or nonvitamin $\mathrm{K}$ antagonist oral anticoagulants: a practical guide to measuring their activity and avoiding diagnostic errors. Semin Thromb Hemost 2015;41(2):208-227

90 Franchini M, Favaloro EJ, Lippi G. Newer hemostatic agents. Semin Thromb Hemost 2015;41(7):802-808

91 Palla R, Peyvandi F, Shapiro AD. Rare bleeding disorders: diagnosis and treatment. Blood 2015;125(13):2052-2061

92 Mumford AD, Ackroyd S, Alikhan R, et al; BCSH Committee. Guideline for the diagnosis and management of the rare coagulation disorders: a United Kingdom Haemophilia Centre Doctors' Organization guideline on behalf of the British Committee for Standards in Haematology. Br J Haematol 2014;167(3):304-326

93 Srivastava A, Brewer AK, Mauser-Bunschoten EP, et al. WFH Guidelines for the Management of Hemophilia. 2nd ed. Available at: http://www.wfh.org/en/resources/wfh-treatment-guidelines? Accessed November 2, 2015

94 Rydz N, James PD. Approach to the diagnosis and management of common bleeding disorders. Semin Thromb Hemost 2012;38(7): 711-719

95 Curnow J, Pasalic L, Favaloro EJ. Treatment of von Willebrand disease. Semin Thromb Hemost 2016;42(2):133-146 